\title{
Analyzing George Bernard Shaw's Portrayal of Women in the Light of Postfeminist
}

\author{
Theory \\ * Dr. Shahid Abbas, Lecturer in English \\ ** Dr. Ijaz Asghar, Assistant Professor \\ ** Qamar Hussain, Lecturer in English
}

\begin{abstract}
The paper aims at investigating the critical opinions about Bernard Shaw's ambivalent relation to feminism. In this regard, the researchers highlight the emerging role of postfeminism and its overlapping elements with the Islamic portrayal of womanhood. Shaw differs from his predecessors drastically - he portrays independent female characters as compared to the invisible and submissive females of the past. Thus, one of the striking features of Shaw's drama is the depiction of liberated women. The Shavian women do not consider men folk as their rivals. There is a shiftfrom powerless to empowered women in academia. The researchers find out that there is an ideological conflict between feminism and Islam but as far as postfeminism is concerned, there is none. Rather, postfeminism propagates and supports the Islamic concept of womanhood thoroughly. It is also worth noting that feminist ideas and ideology have greatly dented the social and politicalfabric of mankind and human civilization in general. Whereas, postfeminism propagates in favor of maintaining a balanced position for womanhood in life which is a balance between social and individual life, and a balance between professional and family life. The purpose of this article is to promote a better understanding of the status of women in Islam and its overlapping and common areas with postfeminism, that is, God has equated female folk at par with their male folk. The research is significant as it challenges the western notion of women in Islam and dispels the erroneous notions of suppression of women in Islam. The prime finding of this research is that postfeminism proclaims equalfooting for men and women in life, as enshrined in the Holy Quran. Further, the researchers lament that just because of myopic-minded people, the world is not making any progress intellectually. The researchers recommend that there is a dire need to promote liberal intellectuals like Shaw who harbor no bias against Islam and Muslims to maintain peace and order in the world.

Keywords: Bernard Shaw, Postfeminism, Islam, Representation of Women

Introduction

Bernard Shaw's knowledge and reading of Islam is extensive as he was impressed by the teaching and preaching of Islam. Shaw holds Islam as a religion of vitality and esteem. In Shaw's opinion, Islam has an inherent tendency to assimilate the ever-changing phases of existence relevant to every age. Moreover, he argues that the prophet Mohammad PBUH is a man of wonderful caliber who is, in no way, an anti-Christ preacher. Shaw esteemed and raised the stature of the Prophet Mohammad PBUH as the Redeemer of mankind. In his opinion, even if Prophet Mohammad PBUH were the dictator of the modern world, he would uplift the problems and sufferings of mankind and would lead the society towards peace, prosperity, and happiness needed in today's time. His remarks can be concluded as follows: "I have prophesied about the faith of Muhammad PBUH that it would be acceptable to the Europe of tomorrow as it is beginning to be acceptable to the Europe of today" (as cited in Ahmed, 1993, p. 33).

Shaw has always professed that Islam is a great religion because of its relevance to modern times. Moreover, the above-mentioned quote provides strong evidence of Shaw's unbiased impression of Islam.
\end{abstract}

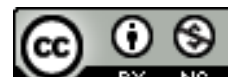

\footnotetext{
* University of Sargodha Email: shahid.abbas@uos.edu.pk

** University of Sargodha Email: ijazasghar@hotmail.com

*** University of Sargodha Email: qamar.hussain@uos.edu.pk
} 


\section{Bernard Shaw's Meeting with the Islamic Cleric}

Shaw met Maulana Abdul Aleem Siddiqui in Kenya in 1935. That meeting was not an ordinary meeting; it was the meeting between two world views - the secular and the religious. Shaw, a great intellectual and an upholder of rationalism, represents the world of secularism, whereas, Maulana, a religious scholar and preacher, represents the sacred and religious model of the world which is based on revelation by God. Samuel (1996) opines that since the dawn of civilization, these two worlds are in clash with each other and the former is trying to subdue the latter and vice versa. Eliot (1922) in The Waste Land talks about the disintegration and hollowness of the modern western civilization at length and asserts that modern man has drifted away into profound disillusionment and misdirection. He has portrayed a Smyrna merchant who has got one eye - the material eye. The implication is that the spiritual eye is completely absent from the life of modern man. However, like all religions, Islam focuses more on the cultivation of spiritual values and insights.

The conversation between the two stalwart figures was very interesting as Shaw kept on raising queries about Islam to Maulana and then listened actively to the responses which were lucid, precise, and informative. The first query put forth by Shaw to test the depth of knowledge is the common recognition of Europe about Islam, that is, it spreads through sword and power. Maulana dispels the impression of Shaw and Europe and dismisses the charge against Islam as a myth. He states that the word "Islam" is derived from 'sal'm' which means peace and harmony as Quran says "There should be no coercion in religion" (2:256). The use of a sword is allowed only to defend when Muslims are under attack, not in the matters of religions as declared by the above-mentioned quote. The brilliant and extensive spread of Islam in the world is due to Muslim observance and adherence to the Quranic commands. The Quran says: "Invite people to the way of your Lord with wisdom and graceful exhortation and dispute with them in the most conciliatory way" $(16,125)$.

Crusades were the outcome of the self-interested and self-ambitious ecclesiastical figures of Christianity. They recognized that the spirit of Islam 'Tawheed' (oneness of God) was one of the hurdles in their path. So, they propagated a reckless campaign against Islam. They waged wars in the name of religion against Muslims by citing tales of atrocities committed by Muslims in which they labeled Muslims as infidels. Now it is a known fact that these church people were responsible for generating and propagating hatreds and cruelty among human beings and consequently, there were protracted wars of hatred between Muslims and Christians. Maulana stated that we cannot blame the teachings of Christianity or Islam for such a worst situation in history. It is quite similar to a situation in which some Muslim rulers or tribes under the motivation of lust invade some land or part of the world. Now for their lust, we cannot condemn Muslims or Islam for such reprehensible deeds. At this point, Bernard Shaw acknowledged that there was no doubt that fanatics on both sides were to be blamed for the Crusades, neither Christianity nor Is lam. And certainly, Islam had been misrepresented purposefully in the past.

Bernard Shaw was also curious to know about the concord between Islam and Christianity. Maulana declared his viewpoint by stating that correspondence is indispensable as the ultimate source of such divine religion is God, the Omnipotent, and the Omnipresent. God has sent down His messengers to preach the strayed humanity from Abraham, Moses, Jesus to Muhammad and their business is to teach subservience and obedience to one God. God has sent his last prophet Muhammad (SAW) and revealed the book The Holy Quran. The Holy Qur'an states: "We ordained for you the religion with which we commanded Noah and which we have revealed unto thee (O Muhammad) and with which we commanded Abraham and Moses and Jesus, saying: Observe this religion and be not divided therein" (42:13).

It is evident from the above dialogue that Shaw had read a translation of the Quran intensively. This was concrete evidence of his broadmindedness and progressiveness.

Another query put forth by Shaw is about the preservation and compilation of the Holy Quran. There is no original manuscript available of the New Testament and various interpretations by the religious heads have produced numerous conflicting texts. Thus, there are great confusions about its injunctions and it is hard for the seeker of truth to digest the text and quench his thirst. The Quran, in contrast, has been preserved in its pristine form, without any minute change. There is a reliable record of every verse of the Quran. Whenever revelation (Wahi) came to the Prophet (SAW), he paid special attention to record it by writing it. To confirm, the Prophet (SAW) directed them to read what they had scribed and, after endorsing it, he throws further light on it. The manuscripts produced by 
Zaid bin Thabit are well-preserved in pristine form in Medina and Constantinople. The available Quranic text is the facsimile of the original and reproduced from it.

The remarkable aspect about this interaction between Shaw and Maulana is that Shaw, who was a western intellectual giant, was not hostile or biased towards Islam. He displayed a great appreciation and respect for Prophet Muhammad (SAW). The modern world has become myopic instead of opening up as the bitter fact is that Western scholars such as G. B. Shaw have almost become rare and hard to find in secular western epistemology. That is why the world is not making any intellectual progress and becoming less safe to live in. On the other hand, it is the vermin of mankind who is controlling the affairs for their petty ulterior motives and misguiding humanity at large. Martin Luther (n.d) aptly delineates that the power of scientific advancement has replaced the once controlling spiritual powers. The worst effect of which is that sciences have only guided missiles but, unfortunately, misguided mankind.

\section{Thesis Statement}

Shaw's portrayal of a woman unfolds the power struggle between the two sexes- male and female as his women protagonists are brave and bold. On the other hand, Shaw supports the conformist woman, who is ready to perform domesticity. Consequently, he seems to fight against the tides of feminism and patriarchy during the harmonizing act of portraying a brave but conventional protagonist.

\section{Research Questions}

This study moves around Shaw's ambivalent attitude towards feminism and post-feminism. In this regard, its main question is to what extent Shaw appreciates Islamic and postfeminist inclinations in his life? And how does Shaw reconcile the depiction of traditional stere otypical character and strong character?

\section{Significance of the Study}

The study is significant as it creates a ripple on modern thought and debate as it deals with the positioning and rights of women. Shaw is a popular figure in our part of the world as he is taught in most of the universities. Shaw is generally considered a notable activist for the liberation of women because of his role in the suffrage movement. The postfeminist tendencies are highlighted and preached, owing to rereading and revisionist critical insights. Thus, the readers may try to integrate postfeminist tendencies in their practical life for smoothness and harmony in practical life.

\section{Postfeminism}

The prefix "post" in postfeminism suggests that feminism is over as it is no longer needed or relevant to modern times. Brooks (1997) thinks that postfeminist does not consider feminism as redundant, but is engaged with feminism critically. The postfeminist tendencies are summarized as below: (Cameron, 2005)

1. The postfeminist does not believe in the essentialist nature of gender, rather gender is performative.

2. In postfeminism, there is a constant urge to retain both aspects of life by integrating career and domesticity. Women are no longer depicted as feeble creatures.

\section{Shaw's Portrayal of Women}

To grasp Shaw's postfeminist tendencies, it is significant to examine the role of power structure and power play being demonstrated by the male and female characters. Shaw's works highlight the power struggle between male and female protagonists. Shaw has portrayed bold and strong female protagonists, which is in sheer contrast with his predecessors who depicted women as weak, feeble, and petty. At times, Shaw reflected an ambivalent attitude towards female characters and he swings from one extreme to the other. That is why his plays have been evaluated with ambivalent attitudes: on the one side, he delineated bold and confident heroines, but on the other side, Shaw's patriarchal and assertive attitude towards women cannot be ignored. Adams (1974) reinforces the same arguments and asserts that Shaw's women are not weak but a type well familiar in English literature: "In play after play, he presents us with various combinations of the traditional figures of temptress, goddess, or mother" (p. 17).

Thus, it is evident that the female protagonist of Shavian plays moves from traditional women to liberated women. As a result, there is an ambivalence of Shaw's attitude towards women, and it requires extensive treatment to unpack gender politics.

George Bernard Shaw is regarded as the forerunner of modern drama since he is one of the most productive dramatists of the $20^{\text {th }}$ century (Innes, 1998). Kaufmann (1965) pays homage to Shaw 
by stating that Shaw was an author par excellence; who wrote a lot during his lifetime. His contribution is immense that contributed to the growth of drama in the $20^{\text {th }}$ century. He opened his eyes in Dublin in a poor family in 1856. Shaw built his career from scratch and become a renowned dramatist in the hierarchy of modern drama. Shaw kicked the bucket at the age of 94, as a prominent socialist, he advocated for social justice and equality.

Bernard Shaw, an iconoc last, has attached the conventions and criticized the Victorian ideals. Hadfield and Reynolds (2013) declare Shaw as the first English dramatist who launched a debate about women's identity. He replaced the weak, submissive and petty heroines of the $19^{\text {th }}$-century drama with the bold and confident. Watson (1964) deals exclusively with the treatment of women characters and asserts that Shaw has portrayed women characters as strong and sensible.

Shaw has portrayed a postfeminist woman through Eliza (Pygmalion) who is no longer a doormat. Instead, she is the one who affirms faith in her abilities. The postfeminist women detest the stereotypical role of the woman - one who is engaged in household chores and who is at the beck and call of her husband. Shaw's Eliza Dolittle is a fine specimen of a post-feminist woman who wants to contribute a vital role in society. Eliza's remarks “...I'm not dirt under your feet” (p. 102) quite appropriately highlight that she wants an independent identity.

\section{Shaw's Construction of Gender}

Shaw is very much against the social and cultural subjugation of women and criticizes the patriarchal system. His female protagonists like Candida and Eliza are portrayed as strong characters who dare to challenge the stereotypes attributed to female folk. They put every effort to fight for the ir liberation and identity. Shaw's plays reflect gender inequalities and gender oppression between men and women, and there is a sincere endeavor for the empowerment of women. (Shaw, 1952; Shaw, 2005)

Feminists are against marriage and condemned it as a tool to perpetuate the sufferings of women. As a philosopher and dramatist, Shaw studies the role of women in the advancement of life. That is why his works are still relevant to our lives and we find inspiration or thoughtfulness in his presentation of female folk. The Quintessence of Ibsenism (1891) is regarded as a ground-breaking feminist manuscript in which a woman is inspired to be bold and strong. In Ibsen's (2006) A Doll's House, the central figure Nora is passive at the beginning of the play, but she changes her gender role and emerges as a liberated one towards the end of the play

Men and women are not rivals but they complement each other. Postfeminist research aims to bring about a social change, i.e., a world which is based on equal rights for women and men. A postfeminist woman is a strong and educated woman who performs her duties actively by maintaining a balance between career and domesticity. Household chores are not drudgery or monotonous ways of life; in fact, there is a celebration of drudgery in postfeminists. Furthermore, a postfeminist woman is not a feeble creature who is always looking for support from her husband. She is a strong woman who is performing her duties actively and contributing towards the advancement of her life.

\section{Woman in Islam}

Islam, as a religion, is primarily based on the words of God. That is why, it is the only religion that provides a complete code of life, and which has been revealed by God for the guidance of mankind. History would bear it out that Islam is the first-ever religion that contributed a great deal towards the restoration of woman's dignity and rights. The Holy Quran's address is general and the word "mankind" is used which categorically declares that He has originated all mankind upon one nature. In The Qur'an, men and women are given equal status and are, therefore, social mates - they complement each other in faith. "O mankind! Be careful of your duty to your Lord Who created you from a single soul and it created its mate and from them, twain hath spread abroad a multitude of men and women" (4:1).

\section{Women during the Prophet's Times}

During the time of the Prophet (SAW), there are no valid reports of women being confined to four walls. Women participated in all activities of the Muslim community to the extent that some even contributed quite actively in battles. Cook (2005) asserts that during the Battle of Uhud, it was women who dressed the wounds of the injured Muslim fighters. From time immemorial, a woman was a saleable commodity just like slaves. With the advent of prophethood and enlightenment, there was a remarkable change in the attitude towards women.

Once a man came to the Prophet (may Allah bless him and grant him peace) and said, "O Messenger of Allah! I intend to go on a (military) expedition, but I have come to ask your advice." He said, "Is 
your mother alive?" He said, "Yes." He said, "Then stay with her, for the Garden is under her feet" (Hasan, p. 63).

"The most complete believers are those who have the best character and the best of you are those who are the best to their wives" (Jami at-Tirmidhi, 1162).

Haykal (1976) proc laims that The Prophet (SAW) again stressed the just treatment of women in his address at the Farewell Pilgrimage. He said: "Do treat your women well and be kind to them for they are your partners and committed helpers" (p. 469).

In short, Muslim men and women enjoy similar rights, and that the discrimination against Muslim women resulted from the distorted image and interpretation of Islam. However, many scholars especially the Westerners have substituted some of the prevalent cultural adaptations in Muslim societies for the Islamic principles or essence. It is to be noted that Islam emphasizes the fraternal relations hip between men and women, not in a form of strife or struggle as it was the bottom line of all strains of feministic movements. In their fight for women's emancipation, feminists are seen at daggers drawn with men. This, however, is contrary to the pure teaching of Islam, where men and women should have congenial and smooth relationships with each other. Muslim women remained engaged in different professions that suited them throughout Islamic history. In Islam, a woman can adopt any occupation she likes or is capable of. Nothing is forbidden to her except what is sinful and this is altogether forbidden to men as well. Empowerment of women in Islam is that sort of empowerment that carries harmony, which is devoid of confrontation and excessive competitiveness.

\section{Conclusion}

The researchers strongly believe that the ultimate aim of feminism is not producing lofty or sublime theories that have a neglected connection with our practical life. Instead of articulating theories which make them alienated and isolated, there is a dire need to encourage and promote a congenial environment among male and female for smoothness and harmony in the relationship. In other words, the objective is to transform gender relations for the good of humanity. Feminists have studied gender with a belief that their research will enhance knowledge and focus on the empowerment of women. This can be achieved by raising awareness and consciousness among females which will eventually stimulate their thinking faculties. The studies in gender and postfeminism research advocate equality and justice among male and female folk. Consequently, Feminism and post-feminism, as a critical movement, are relevant as they are promoting consciousness about the empowerment of women. Thus, they are far from being redundant.

Moreover, the present study is an attempt to look for a panacea of all ills for women. At the outset, it highlights the fact that modern women are having an indecisive stature in sustaining the equilibrium between professional and domestic settings. Women, on the contrary, are pretty satisfied with their traditional role, i.e. as an embodiment of innocence and purity. But, on the other hand, they do not consider them as inferior to men and at par with men as far as vitality and confidence are concerned (Litosseliti, 2006).

This study is a rejoinder to anti-feminist backlashers- those who believe that feminism was a mistake as it has done more disservice than fighting for the liberty of women. Therefore, feminism is no longer needed in the present times as it has outlived its life. As a result, the hallmark feature of post-feminism is that this is a high time for reconciliation between male and female folk. Feminism continues to be an inspiring drive to provide equal opportunities to men and women. In this regard, with genesis postfeminism, there is the advent of the new and powerful women who do not face discrimination. The ideal postfeminist woman aspires to maintain a balance between the two ends careerism and hearth/husband. Thus, the Postfeminist woman is no Cinderella waiting for her prince or they are not fallen women, but they are an angel in a house. As long as men and women exist on earth, their relationship will be studied by using different critical cannons, and thus, feminism cannot be labeled as an obsolete philosophy.

Like postfeminis m, Is lam does not suppress womenfolk in any shape or form. What is labeled by the Western scholars as oppressive is the misreading of Islamic laws by the so-called scholars who have no true knowledge of Islamic law and jurisprudence. Karen Armstrong (2006) makes a striking revelation about the hostile attitude of the western media which is moving towards engaging a new crusade against the Muslims and the first indicator can be traced by Islamophobia: "We can no longer afford to indulge this type of bigotry because it is a gift to extremists" (p. 18). 
Moreover, the status which western women have acquired in the modern era is the result of their long-standing struggle and sacrifice. In the case of Islam, such a dignified status was granted to women by God, the All-Wise and All-Knowing, not under the pressure of women movements for empowerment. It establishes the superiority and divinity of the Holy Quran and the veracity of the message of Islam.

\section{References}

Adams, E. (1974). Feminism and female stereotypes in Shaw. The Shaw Review, 17(1), 17-22. https://www.jstor.org/stable/40682312

Ahmad, K. (Ed.). (1993). Islam: Basic principles and characteristics. Lahore: A.H. Publishers.

Armstrong, K. (2006). Muhammad: Prophet of our time. London: Harper Press.

Brooks, A. (1997). Postfeminisms: Feminism, cultural theory, and cultural forms. London \& NY: Routledge.

Cameron, D. (2005). Language, gender, and sexuality: current issues and new directions, Applied Linguistics, 26 (4), 482-502.

Cook, D. (2005). Women fighting in Jihad. Studies in Conflict \& Terrorism, 28(5), 375-384.

Eliot, T. S. (1922). The wasteland. NY:Boni \& Liveright.

Hadfield, D. A., \& Reynolds. J. (Eds.). (2013). Shaw and feminisms: On stage and off. USA: University Press of Florida.

Hasan, S. ( n.d.). An introduction to the science of Hadith. Darussalam Publishers.

Haykal, M. H. (1976). The life of Muhammad. American Trust Publications.

Ibsen, H. (2006). A doll's house. India: Pearson Longman.

Innes, C. (Ed.). (1998). The Cambridge Companion to George Bernard Shaw. UK: CUP.

Jami at-tirmidhi 1162 - The book on suckling - الرضاع كتاب - Sunnah.com - Sayings and teachings of Prophet Muhammad. (n.d.). Sunnah.com - Sayings and Teachings of Prophet Muhammad. https://sunnah.com/tirmidhi:1 162

Kaufmann, R. J. (1965). G. B. Shaw: A collection of critical essays. USA:Prentice-Hall, Inc.

Litosseliti, L. (2006). Gender and language: Theory and practice. London: Hodder Arnold.

Luther, M. (n.d.). Martin Luther King, jr. quotes. Brainy quote.

Samuel, P. H. (1996). The clash of civilizations and the remaking of world order. New York: Simon $\&$ Schuster.

Shaw, G. B. (1952). Candida: A pleasant play. Baltimore \& Maryland: Penguin Books.

Shaw, G. B. (1891). The quintessence of Ibsenism. Boston: Benj. R. Tucker Publisher.

Shaw, G. B. (2005). Pygmalion: A romance in five acts. London \& NY: Penguin Books.

The Holy Quran. (2018). (M. M. Pickthall, Trans.) Paak Company.

Watson, B. B. (1964). A Shavian guide to the intelligent woman. London: Chatto \& Windus. 